\title{
The Comparative Analysis of Two Songs by Farhad Mehrad: The View of New Historicism
}

\author{
Momene Ghadiri \\ Department of English, University of Isfahan, Isfahan, Iran \\ Email: mome_ghadiri@yahoo.com \\ Ahmad Moinzadeh \\ Department of English, University of Isfahan, Isfahan, Iran \\ Email: moin@fgn.ui.ac.ir
}

\begin{abstract}
This study is an endeavor to compare two pieces of literary texts in terms of the embedded history and culture. The case in point is the poetic discourse data. The data at hand are two Persian songs Jomeh (meaning Friday) and Shabaneh (meaning of the night), sung by the famous Persian legendary rock singer, Farhad Mehrad. Analysis is done within the framework of new historical literary criticism. Results suggested very close interconnectedness within the two songs. Traces of strangulation as well as despair were found in both literary texts reflecting the dominant discourse of the period.
\end{abstract}

Index Terms - literary criticism, new historicism, poetic discourse data, Persian songs

\section{INTRODUCTION}

New historicist Criticism took shape in the late 1970s and early 1980s as opposed to New Criticism and to the critical deconstruction. It views literary texts as "situated" and "negotiated", the oft-disregard fragmentary view lies beyond a work (Putra, 2009). Its intent is the diminishment of the barriers put up between history and art and politics and literature (Cook-Lynn, 1997). It asks critics to attend to literature's shifting political, ideological, and sociological contexts, and in doing so disables the homogenizing abstractions of traditional comparative approaches (Marcus, 2003).

New historicism rejects both traditional historicism's marginalization of literature and New Criticism's enshrinement of the literary text in a timeless dimension beyond history. For new historical critics, a literary text does not embody the author's intention or illustrate the spirit of the age that produced it, as traditional literary historians asserted. Nor are literary texts self-sufficient art objects that transcend the time and place in which they were written, as New Critics believed. Rather, literary texts are cultural artifacts that can tell us something about the interplay of discourses, the web of social meanings, operating in the time and place in which the text was written. In addition, they can do so because the literary text is itself part of the interplay of discourses, a thread in the dynamic web of social meaning. For new historicism, the literary text and the historical situation from which it emerged are equally important because text (the literary work) and context (the historical conditions that produced it) are mutually constitutive: they create each other. Like the dynamic interplay between individual identity and society, literary texts shape and are shaped by their historical contexts (Tyson, 2006). According to new historicism, the circulation of literary and non-literary texts produces relations of social power within a culture.

For new historical literary critics, then, the literary text, through its representation of human experience at a given time and place, is an interpretation of history. As such, the literary text maps the discourses circulating at the time it was written and is itself one of those discourses. That is, the literary text shaped and was shaped by the discourses circulating in the culture in which it was produced. According to this school of thoughts (as cited in Tyson, 2006):

- The writing of history is a matter of interpretations, not facts. Thus, all historical accounts are narratives and can be analyzed using many of the tools used by literary critics to analyze narrative.

- History is neither linear (it does not proceed neatly from cause A to affect and from cause B to affect C) nor progressive (the human species is not steadily improving over the course of time).

- Power is never wholly confined to a single person or a single level of society. Rather, power circulates in a culture through exchanges of material goods, exchanges of human beings, and, most important for literary critics, exchanges of ideas through the various discourses a culture produces.

- There is no monolithic (single, unified, universal) spirit of an age, and there is no adequate totalizing explanation of history (an explanation that provides a single key to all aspects of a given culture). There is only a dynamic, unstable interplay among discourses, the meanings of which the historian can try to analyze, though that analysis will always be incomplete, accounting for only a part of the historical picture.

- Personal identity-like historical events, texts, and artifacts-is shaped by and shapes the culture in which it emerges. Thus, cultural categories such as normal and abnormal, sane and insane, are matters of definition. Put another 
way, our individual identity consists of the narratives we tell ourselves about ourselves, and we draw the material for our narratives from the circulation of discourses that constitutes our culture.

- All historical analysis is unavoidably subjective. Historians must therefore reveal the ways in which they know they have been positioned, by their own cultural experience, to interpret history.

Greenblatt first used the term new historicism in his 1982 introduction to The Power of Forms in the English Renaissance in which he uses Quinn Elizabeth's bitter reaction to the revival of Shakespeare's Richard II on the eve of the Essex rebellion to illustrate the mutual permeability of the literary and the historical (Greenblatt, 2005). Michel Foucault (2002), one of the leading new historicists, explored the relation between discourse and reality of an era. Foucault defines a discourse as language practice, the language that is used by various constituencies such as law, the medicine, the church, etc, to do power relationships between people. In The Archaeology of Knowledge, Foucault posits discourse refers to the general domain of all statements, sometimes as an individualized group of statements, and sometimes as a regulated practice that accounts for a number of statements. Moreover, he asserts, discourse brought people into accounts of its discursive regularities, that there are some external and internal exclusions when discourses are being produced, such a complex system of multiple constraints acts, which bring discourse into existence. There are some external exclusions overcoming the set of discourse procedures including the taboo. In addition, Foucault states another four internal exclusions within the discourse procedures including commentary, author, disciplines, and the rarefaction of speaking subject. Thus, discourses should be seen as groups of statements, which are associated with institutions, which are authorized in some sense and which have some unity of function at a fundamental level. (As cited in Putra, 2009).

Raymond Williams (1980), the Britain leading advocate of new historicism, describes the analysis of all forms of signification, including quite centrally writing, within the actual means and conditions of their production. He coined the term cultural materialism. Both new historicism and cultural materialism seek to understand literary texts historically and reject the formalizing influence of previous literary studies, including new criticism, structuralism and deconstruction, all of which in varying ways privilege the literary text and place only secondary emphasis on historical and social context. Louis Montrose (1992), another major innovator and exponent of new historicism, describes a fundamental axiom of the movement as an intellectual belief in the textuality of history and the historicity of texts. New historicism also draws on the work of Levi-Strauss, in particular his notion of culture as a self-regulating system. The Foucaldian premise that power is ubiquitous and cannot be equated with state or economic power and Gramsci's conception of "hegemony," i.e., that domination is often achieved through culturally orchestrated consent rather than force, are critical underpinnings to the new historicist perspective. The translation of the work of Mikhail Bakhtin on carnival coincided with the rise of the new historicism and cultural materialism (cf. Brewton, 2002).

In its period of ascendancy during the 1980s, new historicism drew criticism from the political left for its depiction of counter-cultural expression as always co-opted by the dominant discourses. Equally, new historicism's lack of emphasis on literariness and formal literary concerns brought disdain from traditional literary scholars. However, New Historicism continues to exercise a major influence in the humanities and in the extended conception of literary studies.

This paper thus aims at comparing two pieces of literary texts in terms of the embedded history and culture. The theoretical framework of the study is that of new historical literary criticism. The data are two Persian songs by the famous Persian legendary rock singer, Farhad Mehrad. The first song, Jome (meaning Friday), was written by famous Persian lyricist, Shahyar Ghanbari and the second one, Shabaneh (meaning of the night), was written by the famous Persian poet, Ahmad Shamloo. Both poems were performed in 1970s before the victory of the Islamic revolution of Iran; however, they were both re-released 1990s after the victory of the Islamic revolution. The analysis in this paper is guided by following questions:

1. What language/events presented in the work reflect the current events of the poet's (singer's) day?

2. How are such events interpreted and presented?

3. How are events' interpretation and presentation a product of the culture of the poet (singer)?

4. Does the work's presentation support or condemn the event?

\section{METHODOLOGY}

\section{A. Materials}

The data analyzed in this section are two Persian songs by the famous Persian legendary rock singer, Farhad Mehrad. The first song, Jomeh (meaning Friday), was written by the Famous Persian lyricist, Shahyar Ghanbari in early 1970s.It was initially released as the video music of the movie, Khodahafez Rafigh (meaning Goodbye Friend), in 1971. The second song, Shabaneh (meaning of the night), was written by the famous Persian poet, Ahmad Shamloo, in the collection Moments and Forever in 1964. The song was then performed by Farhad in 1970s. Both songs were next released in the album, Vahdat ( meaning unity) in 1990s.

\section{B. Procedure}

Each song was first broken into its constituent clauses. The clauses of each song were next analyzed and interpreted in terms of the dominant historical context as well as the cultural and intellectual history of the period. As the songs 
were analyzed within the framework of new historical literary criticism, the poet's intention or the spirit of the age that produced it, was not taken into consideration.

\section{ANALYSIS AND DISCUSSION}

In the following analysis, it is tried that the aforementioned research questions be answered.

Shahyar Ghanbari's Jomeh (1971) and Ahmad Shamloo's Shabaneh (1964) were both published during one of the Iranian greatest periods of the oppression, cruelty, extravagance, and corruption. Mohammad Reza Pahlavi's decisions and policies in 1970s, before the victory of the Islamic revolution (1979), were strongly faced with dissatisfactions. The basic functional failures within the regime including an over-ambitious economic program that brought economic bottlenecks, shortages, inflation, and accelerating gap between rich and poor in the society led to many protests and demonstrations. Pahlavi's regime was also known for its autocracy, its focus on modernization and westernization and for its disregard for religious and democratic measures in Iran's constitution. Leftist, nationalist and Islamist groups attacked his government for violating the Iranian constitution, political corruption, and the political oppression.

Many of the protests were strongly oppressed by the security forces, Savak (secret police). However they were unable to deal with the large number of the protests and demonstrations as the extraordinarily large size of the anti-shah movement meant that there were too many protesters to arrest, and that the security forces were overwhelmed.

Thus, the dominant discourse of the time is that of strong strangulation, despair, and oppression. The first song Jomeh (1971) was produced and performed as the tremendous criticism against the increasingly oppressive government of Shah Mohammad Reza Pahlavi and helped cement its reputation as a serious violator of the human rights. The brutal crackdown after the 15 Khordad (5 June) uprising (1963) convinced many young critics of the Shah's government that there was no hope for peaceful reform of the system. Rather, Iranian activists saw the only way forward as revolutionary overthrown of the entire monarchical system. They believed that small armed attacks would shock the system and create space for necessary political action and arouse the masses.

On 8 February 1971, one of this small opposition groups, the leftist guerrilla, launched their first attack on the gendarmerie post of the small village of Siahkal, situated close to Lahijan. The attack proved disastrous: the group's contact in the village, a school teacher, had already been captured by Savak, and the local farmers immediately turned against the guerillas. The government mobilized a tremendous military response, much larger than anticipated by the guerillas. Thousands of troops and several helicopters scoured the country-side for days until ultimately all were killed or captured.

Although the Siahkal assault was unquestionably a military defeat, it proved a political and propaganda turning point in the struggle against the Shah, as it pointed out the development of a hitherto unseen level of resistance against the imperial regime. The government's overwhelming response only served to highlight the Shah's fear of armed resistance and imbued the fighters with a popular mystique. Siahkal eventually became known as the foundation of the anti-Shah guerilla movement and as a major step in the struggle that led to the overthrow of the Shah.

Jome (Friday) reflects the major tenets of the discourse of the period and the incident of Siahkal through the thorough characterizations and simple imagery, which contributes significantly to the intensity of the song. The choice of Jome (Friday) exactly refers back to the day of the incident. The use of the terms "sad ", " black clouds", "mourning clothes", " dense clouds ", "blood" in the song largely reflect the discourse of the darkness, despair and oppression. "Blood is dripping from the black cloud" represent the dominant bloody atmosphere of the violence and insecurity in the society indicating the death of the martyrs of the incident.

The verse "Fridays don't come to an end" clearly suggests lyricist's despair of changing the time. In addition, the lyricist's exaggeration and vicious circle of the verse "Blood is dripping from the black cloud" and "On Fridays blood is dripping, and not rain" emphasizes the dominant discourse of the time that the period of despondency, oppression, and torture is never ended up. The lyricist's desperation of ignoring the dominant oppression and torture of the society is clearly represented when "Wish I could close my eyes, but I can't".

The lyricist's exaggeration concerning the age of Friday reflect the lyricist boredom of lingering the period of torture suggesting that the time is never ended up. "And cries with sealed lips," chiefly reflect the armed uprisings and strong strangulation which would not allow any verbal criticism, as well. Also the ambiguity in the last stanza of the lyric, " Friday is the time to leave, the season of forsaking " meant that we should either leave the county or revolutionize and being martyred, suggest the only way forward as revolutionary overthrown of the entire monarchical system. All in all the discourse of the lyric is that of strong oppression, torture, boredom, desperation, despair, strangulation and despondency.

Ahmad Shamloo's Shabaneh (1964) also reflect the discourse of strong oppression, boredom, monotony, desperation, despair, strangulation and despondency. Shamloo's poetry is complex, yet his imagery, which contributes significantly to the intensity of his poems, is simple. In the first stanza, Shamlou nicely characterizes monotony and strangulation of the society with different metonymies: "alleys" represent the paths, having been narrowed down, indicating hindering the path of development and improvement in the society. "Shops" represent the people's livelihood, having also been shut, indicating impeding the economic growth in the society. "Houses" represent the places of living, having been darkened, indicating despondency, monotony and desperation of the lives. "Roofs" represent the shelters, having been 
collapsed, indicating the violence and insecurity in the society. The society is composed of the collection of the "alleys", "shops", "houses" as well as "roofs".

"Tars and violins are reduced to silence." (musical instruments) represent the lack of art and artists, in other words monotony, in the society. Art is mostly considered as a way of putting the society forward. "The dead" represent the people of the society being suppressed and surrendered. The poet nicely compared the people with the "oil-lamp" which has the oil, the sign of living, but doesn't burn out indicating that people are alive but have no motivation of changing the situation and just have surrendered. The poet's despair of any change is quite demonstrated through his "no hope of the good" and "no complaint of the bad". In addition, the poet simply separated himself from the people of the society and again emphasized his desperation of any movement in the society.

The vicious circle of the first stanza in the poem emphasizes the fact that the period of strong oppression, boredom, monotony, desperation, despair, strangulation and despondency is eternal and nothing can change the dominant atmosphere of the society.

In spite of many similarities having been found within the two literary texts, some minute differences were also investigated. In the first song, Jomeh, the lyricist is hopeful that the armed uprising may change the situation and complains his friends of being disloyal to him, as in the second song, Shabaneh, the poet is quite desperate without any criticism of the bad or those who have been surrendered being assure that no movement will change the society. In addition, the second song, Shabaneh, is more monotonous than the first song, Jomeh, and poet's despondency is more obvious than the first.

\section{FINDINGS AND CONCLUSION}

This study is an attempt to compare two pieces of literary texts in terms of the embedded history and culture .The data at hand are two Persian songs Jomeh (meaning Friday) and Shabaneh (meaning of the night), sung by the famous Persian legendary rock singer, Farhad Mehrad. Analysis is done within the framework of new historical literary criticism.

Both songs were published during one of the Iranian greatest periods of the oppression, cruelty, extravagance, and corruption, and may be considered as a strong reaction against the increasingly oppressive government of Shah Mohammad Reza Pahlavi and helped cement its reputation as a serious violator of the human rights. Thus, the dominant discourse of the time is that of strong oppression, boredom, monotony, desperation, despair, strangulation and despondency, which can be traced within both literary texts.

In spite of many similarities having been found within the two literary texts, some minute differences were also investigated: the traces of monotony, desperation, despondency of any change is more obvious in the second song; as the discourse of the first lyric may be considered as that of armed uprising and that the lyricist is hopeful that revolutionary overthrown might change the dominant insecure atmosphere of country.

It should be noted that for new historical literary critics, the literary text, is an interpretation of history, not facts. As such, analysis will always be incomplete, accounting for only a part of the historical picture, as all historical interpretations are unavoidably subjective. The literary text maps the discourses circulating at the time it was written and is itself one of those discourses. Likewise, our interpretations of literature shape and are shaped by the culture in which we live.

\section{APPENDIX A JOMEH (FRIDAY)}

\author{
Persian \\ Too-ye ghab-e khis-e in panjereha \\ Aksi az jome-e ghamgin mibinam \\ Che siahe be tanesh rakht-e aza \\ Too cheshash abra-y-e sangin mibinam \\ Dare az abr-e siah khoon micheke \\ Jomeha khoon jay-e baroon micheke \\ Nafasam dar nemiad, jomeha sar nemiad \\ Kash mibastam cheshamo, in azam bar nemiad \\ Dare az abr-e siah khoon micheke \\ Jomeha khoon jay-e baroon micheke \\ Omre jome be hezar sal mirese \\ Jomeha gham dige bidad mikone \\ Adam az daste khodesh khaste mishe \\ Ba laba-y-e baste faryad mikone \\ Dare az abr-e siah khoon micheke \\ Jomeha khoon jay-e baroon micheke \\ Jome vaght-e raftane, mosem-e delkandane \\ Khanjar az posht mizane, oonke hamrahe man-e
}

\section{English Translation}

In the wet frame of these windows,

I see a picture of sad Friday.

How black is the mourning clothes it has on,

I see dense clouds in its eyes.

Blood is dripping from the black cloud,

On Fridays blood is dripping, and not rain!

I'm out of breath; Fridays don't come to an end,

Wish I could close my eyes, but I can't.

Blood is dripping from the black cloud,

On Fridays blood is dripping, and not rain!

Fridays have lived for thousands years,

Fridays are full of deep sadness,

Man is tired of himself,

And cries with sealed lips,

Blood is dripping from the black cloud,

On Fridays blood is dripping, and not rain!

Friday is the time to leave, the season of forsaking,

Stabs my back with a dragger, the one who is with me, 
Dare az abr-e siah khoon micheke Jomeha khoon jay-e baroon micheke
Blood is dripping from the black cloud,

On Fridays blood is dripping, and not rain

\section{APPENDIX B SHABANEH (OF THE NIGHT)}

\author{
Persian \\ Koocheha Barikan, \\ dokoona bastes, \\ Khooneha tarikan, \\ tagha shikastas. \\ Az seda oftade tar o kamoonche, \\ Morde mibaran, kooche be kooche. \\ Negah kon! mordeha be morde nemiran, \\ Hata be sham-e joon seporde nemiran. \\ Shekl-e fanoosian ke age khamooshe, \\ Vase naf nis hanoo ye alam naf tooshe! \\ Jamaat! man dige hosele nadaram! \\ Be khoob omid o az bad gele nadaram! \\ Garche az digaroon fasele nadaram, \\ Kari ba kare in ghafele nadaram. \\ Koocheha Barikan, \\ dokoona bastes, \\ Khooneha tarikan, \\ tagha shikastas. \\ Az seda oftade tar o kamoonche, \\ Morde mibaran, kooche be kooche.
}

\author{
English Translation \\ The alleys are narrow, \\ The shops are shut, \\ The houses are dark, \\ The roofs are collapsed. \\ Tars and violins, are reduced to silence, \\ They are shouldering a dead body/ corpse, alley to alley. \\ Look! The dead are not like the dead, \\ Not even like a candle in the throes of death. \\ They are like an oil-lamp which is put out, \\ But not for the oil, as there's a lot of oil in that! \\ People, I'm not patient anymore! \\ I have neither hope to "good", nor complaint about "bad" \\ Although I don't keep aloof from others, \\ I have nothing to do with this crowd. \\ The alleys are narrow, \\ The shops are shut, \\ The houses are dark, \\ The roofs are collapsed. \\ Tars and violins, are reduced to silence. \\ They are shouldering a dead body/ corpse, alley to alley.
}

\section{REFERENCES}

[1] Bakhtin, M. (1981). The Dialogic Imagination. Trans. Emerson, C. \& Holquist. M. Austin, TX: University of Texas Press.

[2] Branningan, J. (1998). New Historicism and Cultural Materialism. Basingstoke: Macmillan Press.

[3] Brewton,V. (2002). Literary Theory. Florence: University of North Alabama.

[4] Colebrook, C. (1998). New Literary Histories: New Historicism and Contemporary Criticism. Manchester: Manchester University Press.

[5] Collins, S. L. (1989). Where is the History in the New Literary Historicism? The case of English Renaissance. Annals of Scholarship 6, 231-247.

[6] Cook-Lynn, E. (1997). Who Stole Native American Studies? Wicazo Sa Review, 12(1), 9-28.

[7] Foucault, M. (2002). The Archeology of Knowledge. Trans. Smith A. M. London and New York: Routledge.

[8] Foucault, M. (1980). Power Strategies, in Power/knowledge: Selected Interviews and Other Writings 1972-1977, ed by Gordon, C.\& tr by Gordon, C. et al. New York: Pantheon Books.

[9] Gallagher, C. \& Greenblatt, S. (2000). Practicing New Historicism. Chicago: University of Chicago Press.

[10] Greenblatt, S. (2005). The Greenblatt Reader. Ed. Payne, M. Oxford: Blackwell.

[11] Greenblatt, S. (1991). Learning to Curse: Essays in Early Modern Culture. New York: Routledge.

[12] Greenblatt, S. (1988). Shakespearean Negotiations: The Circulation of Social Energy in Renaissance England. Berkeley: University of California Press.

[13] Greenblatt, S. (1980). Renaissance Self-Fashioning: From More to Shakespeare. Chicago: University of Chicago Press.

[14] Http://de.wikipedia.org/wiki/New Historicism.

[15] Http://de.wikipedia.org/wiki/ Iranian Revolution.

[16] Http://de.wikipedia.org/wiki/Hassan Zia-Zarifi

[17] Marcus, S. (2003). Same Difference? Transnationalism, Comparative Literature, and Victorian Studies. Forum on Transnationalism, 45(46), 77-686.

[18] Mills, S. (2005). Michel Foucault. London: Routledge.

[19] Montrose, L. (1992). Redrawing the Boundaries: The Transformation of English and American Literary Studies. Eds. Greenblatt, S. \&Giles, G. New York: Modern Language Association.

[20] Pieters, J. (2001). Moments of Negotiation: The New Historicism of Stephen Greenblatt. Amsterdam: Amsterdam University Press.

[21] Putra, N.D. (2009). New Historicism: A New Approach on Literature. The Essay-New Historicism Reading, 1-8.

[22] Smart, B. (2002). Michel Foucault: Revised Edition. New York: Routledge.

[23] Taine, H. (1897). History of English Literature. London: Chatto \&Windus.

[24] Tyson, L. (2006). Critical Theory Today: A User-Friendly Guide. London, Rutledge.

[25] Williams, R. (1980). Problems in Materialism and Culture. London: Verso.

Momene Ghadiri is an MA candidate of TEFL at university of Isfahan, Isfahan, Iran. Her main areas of research are English Teaching, Discourse Analysis, and Sociolinguistics. She holds a BA degree in English translation. 
Ahmad Moinzadeh is currently Assistant Professor of Linguistics at Department of English, Faculty of Foreign Languages, University of Isfahan, Isfahan, Iran. He has instructed BA, MA, and PhD courses at this department for many years. His main areas of research are Syntax, Comparative/Contrastive Linguistics, Morphology, and Language Acquisition. He holds a PhD degree in Linguistics, an MA degree in Linguistics, and a BA degree in English Language and Literature. 